\title{
Differential p38-dependent signalling in response to cellular stress and mitogenic stimulation in fibroblasts
}

\author{
Dagmar Faust ${ }^{1}$, Christina Schmitt ${ }^{1}$, Franz Oesch¹, Barbara Oesch-Bartlomowicz ${ }^{1}$, Ilona Schreck ${ }^{2}$, Carsten Weiss ${ }^{2}$ and \\ Cornelia Dietrich $^{1^{*}}$
}

\begin{abstract}
p38 MAP kinase is known to be activated by cellular stress finally leading to cell cycle arrest or apoptosis. Furthermore, a tumour suppressor role of p38 MAPK has been proposed. In contrast, a requirement of p38 for proliferation has also been described. To clarify this paradox, we investigated stress- and mitogen-induced p38 signalling in the same cell type using fibroblasts. We demonstrate that - in the same cell line - p38 is activated by mitogens or cellular stress, but p38-dependent signalling is different. Exposure to cellular stress, such as anisomycin, leads to a strong and persistent p38 activation independent of GTPases. As a result, MK2 and downstream the transcription factor CREB are phosphorylated. In contrast, mitogenic stimulation results in a weaker and transient p38 activation, which upstream involves small GTPases and is required for cyclin D1 induction. Consequently, the retinoblastoma protein is phosphorylated and allows G1/S transition. Our data suggest a dual role of p38 and indicate that the level and/or duration of p38 activation determines the cellular response, i.e either proliferation or cell cycle arrest.
\end{abstract}

Keywords: p38 MAPK, Signalling, Cellular stress, Mitogens, Fibroblasts

\section{Background}

The family of mitogen-activated protein kinases (MAPKs) involves ERKs (extracellular signal-regulated kinases), JNKs (c-Jun-N-terminal kinases) and p38 MAPKs. They are proline-directed Ser/Thr kinases mediating a variety of cellular responses due to numerous extracellular stimuli. While the ERK pathway is preferentially induced by mitogens, p38 and JNK are generally activated by inflammatory cytokines and cellular stress, such as hyperosmolarity, heat shock, genotoxic compounds, UV light, $\gamma$-irradiation, metabolic stress, and protein synthesis inhibition [for review see [1-4]]. Mammalian p38 was first cloned by Han and coworkers and revealed close homology to the yeast osmosensing HOG1 [5]. A common response of p38 activation by cellular stress is cell cycle arrest or apoptosis. Moreover and consistent with its role in cell cycle regulation, p38 is involved in oncogene-induced senescence,

\footnotetext{
* Correspondence: cdietric@uni-mainz.de

'Institute of Toxicology, Medical Center of the Johannes Gutenberg-

University, Obere Zahlbacherstr. 67, 55131 Mainz, Germany

Full list of author information is available at the end of the article
}

replicative senescence, differentiation, and DNA-damage response [for review see [6]]. For instance, several reports indicate an inhibitory role of $\mathrm{p} 38$ in proliferation in the mouse fibroblast cell line NIH3T3. Tunicamycin-treatment causes activation of $\mathrm{p} 38$ resulting in phosphorylation of GADD153 finally leading to cell cycle block [7]. G1arrest is also detected in response to arsenite, which is mediated by a p38-dependent increase in p21 [8]. Constitutive expression of oncogenic ras results in sustained activation of p38 and inhibition of proliferation [9]. Consistent with a negative role in cell cycle progression, expression of active MKK3/6 induces G1 arrest in the same cell line [10]. Similar data has been obtained in rhabdomyosarcoma cells, in which p38 activation results in G1-arrest and differentiation [11]. We recently revealed that sustained activation of p38 in response to high cell density is involved in the signalling cascade of contact-inhibition in murine and in human FH109 fibroblasts by regulating levels of the Cdk-inhibitor p27 [12].

However, several reports suggest that p38 is also activated in mitogenic pathways. Maher described a 
requirement of p38 for bFGF-induced (but not for PDGF-stimulated) cell proliferation in Swiss3T3 fibroblasts [13]. A similar role has been proposed in hepatocytes after EGF- and insulin-treatment [14], and ERK cooperates with p38 in G-CSF-stimulated hematopoietic cell proliferation [15]. A proliferative role of p38 has also been described in breast cancer-, chondrosarcoma-, and melanoma cells [16-18]. These reports suggest a proliferative function of p38 in contrast to the above mentioned role of p38 in stress response and cell cycle arrest.

Some simple explanations for these discrepancies could be dependence on stimulus, cellular context or cell-type specificity. For example, p38 activation by one type of stimulus might lead to different biological outcomes, i.e. proliferation or growth arrest, dependent on cell type. Alternatively, distinct stimuli could induce p38 signalling via different routes in the very same cell type thus triggering diverging responses. Unfortunately, the proliferative and growth inhibitory role of $\mathrm{p} 38$ has been investigated so far only in different cell lines and thus the possibility of divergent p38 signalling downstream of different stimuli in simply the same cell line is poorly understood. Therefore we studied p38 signalling in human and murine fibroblast cell lines and compared the signalling cascades up- and downstream of p38 in response to mitogens and cellular stress. Here we show that mitogen-induced proliferation in NIH3T3 and FH109 fibroblasts can be substantially blocked by the compound SB203580, which is a selective inhibitor of p38 [19] again demonstrating that p38 mediates cellular proliferation. Since p38 also regulates cell cycle arrest in the same cell lines as mentioned above, we analysed mitogen- and stress-induced activation of p38 in NIH3T3 and FH109 fibroblasts. We provide evidence for a dual role of p38 in cell cycle control and suggest that the level and/or the duration of p38 activation might determine the cell's decision to proliferate or to induce cell cycle arrest. We show that in NIH3T3 and FH109 fibroblast cell lines mitogenic stimuli lead to a weak and transient phosphorylation of $\mathrm{p} 38$, which is absolutely required for G1/S-transition whereas anisomycin induces a strong and sustained activation of p38. We further revealed that the signalling cascades involving p38 activation after serum- and stress-treatment differ. While mitogenic activation of p38 upstream involves small GTPases and downstream leads to cyclin D1 expression, anisomycin-dependent activation of p38 is independent of GTPases and leads to phosphorylation of MK2 and finally CREB. In conclusion, our data provide an example of differentially wired p38 signalling in response to distinct stimuli, which results in specific outputs such as stress-induced cell cycle arrest and mitogen-induced proliferation.

\section{Results}

\section{Involvement of p38 in mitogen-induced proliferation}

Cellular stress is known to induce p38-dependent cell cycle arrest in NIH3T3 cells as does constitutive activation of p38 as mentioned above [7-10]. To investigate whether p38 is also involved in cell cycle progression, NIH3T3 were rendered quiescent by serum-depletion and then stimulated with fetal calf serum (FCS), platelet-derived growth factor- $\beta$ (PDGF $\beta$ ) or basic fibroblast growth factor (bFGF) in the absence or presence of the p38-specific inhibitor SB203580 [19] or after p38 $\alpha$-knock-down via transient transfection of siRNA targeted against murine p38 $\alpha$. p38 $\alpha$ is the dominant isoform in NIH3T3 and FH109 fibroblasts [[20], and own unpublished observations]. As expected, stimulation with FCS or the growth factors resulted in a marked increase in DNA-synthesis as determined by $\left[{ }^{3} \mathrm{H}\right]$ thymidine incorporation. This increase was substantially blocked by SB203580, which was added one hour before the mitogens and was then present throughout the entire experiment, or after p38 $\alpha$ knock-down (Figure 1A, B). Similar results were obtained in the human fibroblast cell line FH109 (Additional file 1). As stated below using the transcription factor CREB as a substrate, we demonstrated that SB203580 was indeed active for at least $24 \mathrm{~h}$ as a p38 inhibitor. Furthermore, we confirmed, that siRNA-mediated knock-down of p38 $\alpha$ decreases growth factor-induced p38 phosphorylation. Importantly, phosphorylation of ERK1/2 was not affected up to $4 \mathrm{~h}$ (Additional file $2 \mathrm{~A}, \mathrm{~B}$ ). In line with the knock-down experiments, also the p38-inhibitor SB203580 did not alter mitogen-induced ERK1/2 phosphorylation at early time points, but decreased ERK1/2 phosphorylation at later time points (Additional file 2C). These data indicate that SB203580 does not directly inhibit ERK1/2 function, but that p38 activity seems to be required for sustained ERK1/2 phosphorylation. Although SB203580 is considered to be a highly specific inhibitor of p38 [19], inhibition of JNK2 has been described [21]. Here, phosphorylation of the JNK substrate c-Jun in response to anisomycin, a wellknown activator of JNK, is not inhibited by SB203580, but as expected by the JNK-inhibitor SP600125 (Additional file $2 \mathrm{D})$. Taken together, the previous experiments show that p38 is activated after mitogenic stimuli and is required for growth factor-induced re-entry of quiescent fibroblasts into the cell cycle.

To investigate whether p38 is also required for continuous proliferation, cells were seeded and cultured in $10 \%$ FCS up to $72 \mathrm{~h}$ in the absence or presence of SB203580. Figure $1 \mathrm{C}$ clearly shows that continuous proliferation of NIH3T3 cells is impaired in the presence of SB203580.

\section{Activation of p38 after mitogenic stimuli and cellular stress}

p38 needs to be activated by dual phosphorylation on threonine (180) and tyrosine (182) by MKK3 or MKK6 [22]. We therefore made use of a phospho-specific anti- 


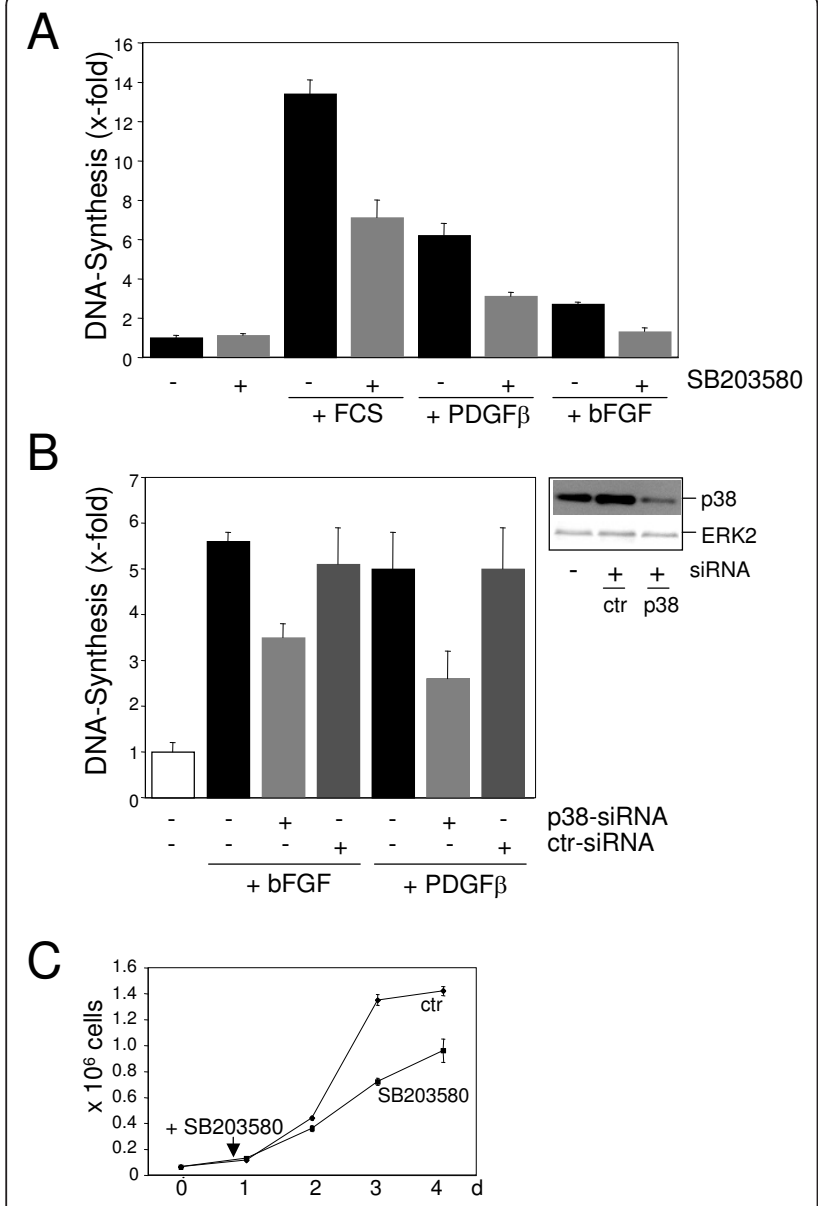

Figure 1 Effect of impairment of p38 function on mitogeninduced DNA-synthesis. (A) Serum-starved NIH3T3 cells were either not pretreated or preincubated for $1 \mathrm{~h}$ with SB203580 (10 $\mu \mathrm{M})$. The cells were then stimulated with $10 \%$ FCS, PDGF $\beta$ or bFGF (each $50 \mathrm{ng} / \mathrm{ml}$ ) for $20 \mathrm{~h}$ and labelled with $\left[{ }^{3} \mathrm{H}\right]$ thymidine for additional $4 \mathrm{~h}$ in the absence or presence of SB203580. Incorporated radioactivity was determined by liquid scintillation spectrometry. Results are given as $x$-fold induction of $\left[{ }^{3} H\right]$ thymidine incorporation compared to unstimulated, serum-starved cells and are the average \pm Sx of a number of four for each run of treatment. The results represent one out of three independent experiments each leading to similar results. (B) $\mathrm{NIH} 3 \mathrm{~T} 3$ cells were transiently transfected with siRNA directed against p38 $\alpha$ or with control siRNA. Knock-down is shown by Western blot analysis. Cells were serum-starved and then stimulated with bFGF or PDGF $\beta$. DNA-synthesis was determined as described in (A). (C) $0.06 \times 10^{6} \mathrm{NIH} 3 \mathrm{~T} 3$ cells were seeded in $4.5 \mathrm{~cm}^{2}$ dishes. Cells were either not treated or treated with SB203580 $(10 \mu \mathrm{M}) 4 \mathrm{~h}$ after seeding and then cultured in the absence or presence of SB203580 for another $68 \mathrm{~h}$. Cells were counted in a hemocytometer. The results are expressed as the average $\pm \mathrm{Sx}$ of a number of four for each time point and treatment. The results represent one out of two independent experiments.

p38-antibody (T180/Y182) and performed Western blot analysis to compare $\mathrm{p} 38$ kinase activation in response to mitogens and cellular stress. Indeed, time course analysis revealed that p38 was clearly, but transiently phosphorylated after FCS- and bFGF-stimulation in serum-starved NIH3T3 cells (Figure 2A). In contrast, treatment with the cellular stressors and known inducers of p38 anisomycin or sorbitol [for review see [23]], results in a stronger and persistent phosphorylation of p38 (Figure 2B). Similar results were obtained in FH109 fibroblasts (Additional file 3).

Cell cycle proteins are differentially affected by p38 signalling after mitogenic stimuli or cellular stress

We next investigated cell cycle proteins as potential p38 downstream targets by Western blot analysis. A key regulator of G1/S-transition is the retinoblastoma protein (pRB). When phosphorylated, pRB dissociates from the transcription factor E2F thereby allowing transcription of S-phase specific genes, such as cyclin A, and subsequently entry into S-phase [24]. Using a phospho-specific antipRB-antibody we detected - as expected - phosphorylation of $\mathrm{pRB}$ after stimulation with FCS which reached maximal levels after $14 \mathrm{~h}$ and persisted thereafter (Figure 3A). Phosphorylation of $\mathrm{pRB}$ was also observed by a shift in the electrophoretic mobility of pRB. Importantly, preincubation with SB203580 prevents pRB phosphorylation (Figure 3B) indicating that p38 is required for S-phase entry. Consistent with the inhibition of $\mathrm{pRB}$ phosphorylation, maintained serum-induced expression of cyclin A was also abolished in the presence of SB203580 (Figure 3C).

Phosphorylation of $\mathrm{pRB}$ is mediated by cyclin-dependent kinases which are regulated by cyclins, namely by the Cdk4/cyclin D1 complex and the Cdk2/cyclin E complex. Hence, downregulation of cyclin D1 will lead to impaired phosphorylation of pRB. Indeed, serum-induced expression of cyclin D1 is strongly attenuated in the presence of SB203580 (Figure 3C). Downregulation of cyclin D1 expression by SB203580 was still detected $24 \mathrm{~h}$ after mitogenic stimulation (Additional file 4A). Thus, inhibition of p38 does not merely delay cyclin D1 expression, but prevents cyclin D1 induction. Similar findings were obtained in FH109 cells (Additional file 4B).

In contrast, anisomycin and sorbitol treatment led to a complete loss of cyclin D1 expression. However, this effect could not be reversed by SB203580 (Figure 3D). Hence, downregulation of cyclin D1 in response to cellular stress is probably mediated in addition by other stress kinases or pathways in NIH3T3 cells.

\section{Transcription factors are differentially targeted by p38 after mitogenic stimuli or cellular stress}

We next focussed our interest on known transcription factors. In co-transfection and in vitro experiments, the transcription factors activating transcription factor-2 (ATF-2) and cAMP-responsive element-binding protein (CREB) have been described to be excellent p38 substrates [25-27]. We therefore performed Western blot analysis with 


\section{A}

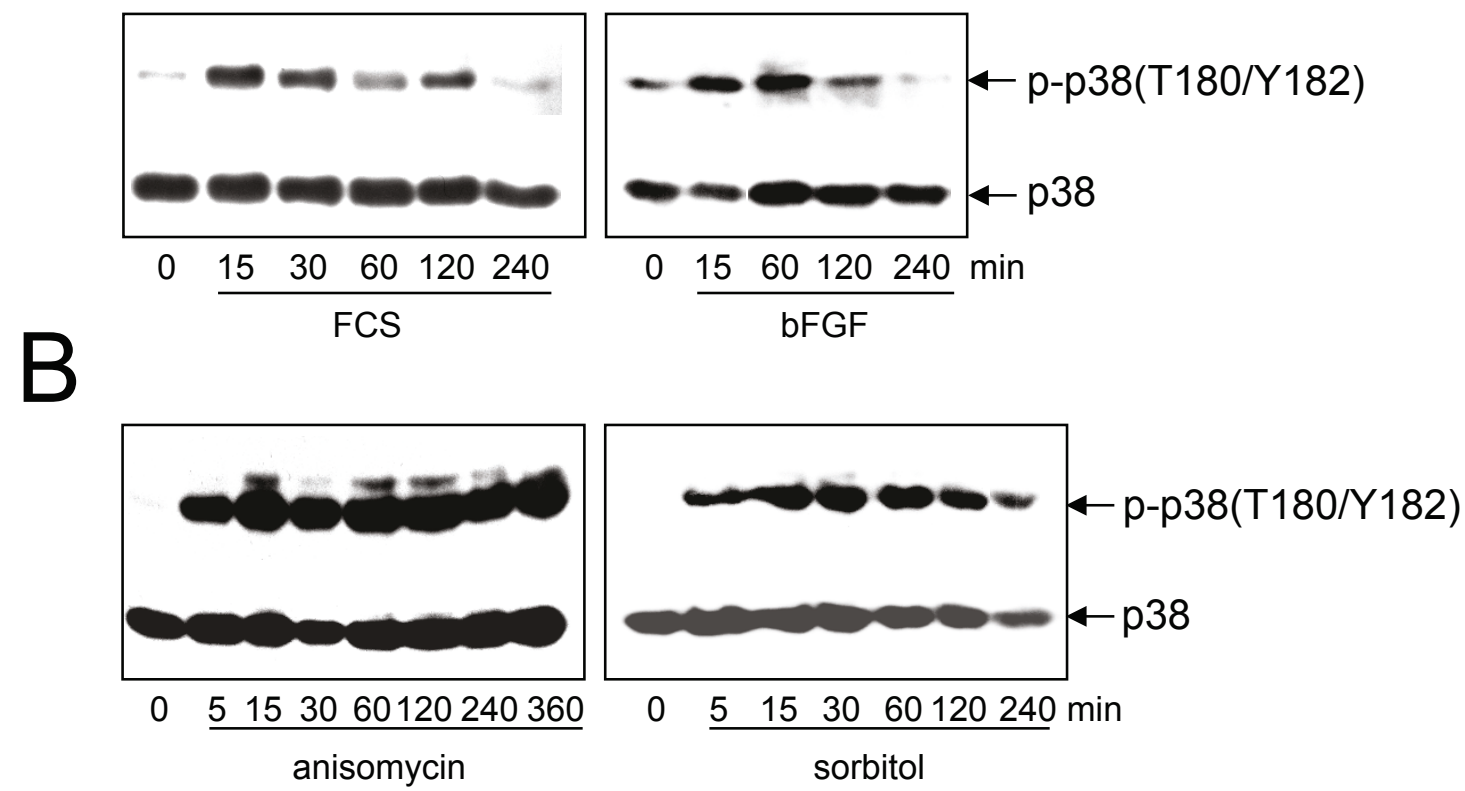

Figure 2 Stimulation of p38 by mitogens and cellular stress. (A, B) Serum-starved NIH3T3 cells were treated with FCS or bFGF (A), anisomycin $(10 \mu \mathrm{g} / \mathrm{ml})$ or sorbitol $(400 \mathrm{mM}) \mathbf{B})$ and total cell extracts prepared at the indicated time points. Western blot analysis was performed using a phospho-specific (T180/Y182) anti-p38-antibody. The blots were stripped and reprobed with an anti-p38-antibody to control equal loading. Data from a single experiment are shown. Similar results were obtained in three independent experiments.

phospho-specific anti-ATF-2- and anti-CREB-(also recognizing ATF-1) antibodies after FCS- and anisomycin-exposure in the absence or presence of SB203580. To our surprise, ATF-2 phosphorylation was not inhibited by SB203580 neither after FCS- nor after anisomycin-treatment (Figure 4A). In contrast, phosphorylation of ATF-2 was strongly blocked by the JNK-inhibitor SP600125. Cotreatment of cells with both inhibitors of JNK and p38 did not further reduce ATF-2 phosphorylation demonstrating that JNK is the responsible kinase for ATF-2 phosphorylation in response to anisomycin (Figure 4B). These results argue against a requirement for $\mathrm{p} 38$ in ATF-2 phosphorylation in fibroblasts. Interestingly, also CREB phosphorylation in response to FCS-stimulation was not affected by SB203580 ruling out an involvement of p38 (Figure 4C). In contrast, anisomycin-induced phosphorylation of CREB/ATF-1 was totally abolished in the presence of SB203580 even after $24 \mathrm{~h}$ (Figure 4C) indicating that p38 is the only kinase mediating CREB phosphorylation under these conditions. Similar results were obtained in FH109 cells (Additional file 5). Consistent with these data, phosphorylation of MK2, which is known to mediate p38dependent CREB phosphorylation [27,28], was only detectable after anisomycin-treatment, but not after FCSstimulation, neither after prolonged treatment (Figure 4D), nor when analysing very early time points (Figure 4E).
Anisomycin-induced CREB phosphorylation is mediated by the p38-MK2 pathway, as phosphorylation of MK2 in response to anisomycin was totally abolished in the presence of SB203580.

FCS-, but not anisomycin-induced phosphorylation of p38 is dependent on GTPases

We next investigated the involvement of small GTPases, comprising Ras, Rap and the family of Rho proteins (Rac, Rho and Cdc42) in p38 activation. Cells were preincubated with bacterial toxins to inhibit GTPase activity [for review see [29-31]]. Effective concentrations of the bacterial toxins were prior titrated by visualising changes in the integrity of the cytoskeleton via FITC-phalloidin staining (see addional file 6A). After preincubation with the toxins, cells were stimulated with FCS or anisomycin for $30 \mathrm{~min}$ and Western blot analysis was then performed with the phospho-specific anti-p38-antibody. Figure 5A clearly demonstrates that pretreatment with Lethal Toxin (LT) and Toxin B (TB), but not with C2IN-C3 toxin (C3) totally abolished serum-stimulated $\mathrm{p} 38$ phosphorylation. This indicates that FCS-dependent phosphorylation of p38 is dependent on small GTPases, but probably independent of Rho itself. None of the toxins (LT, TB, C3) was able to block anisomycin-induced p38 phosphorylation (Figure $5 \mathrm{~B}$ ). The specificity of the toxins was further 


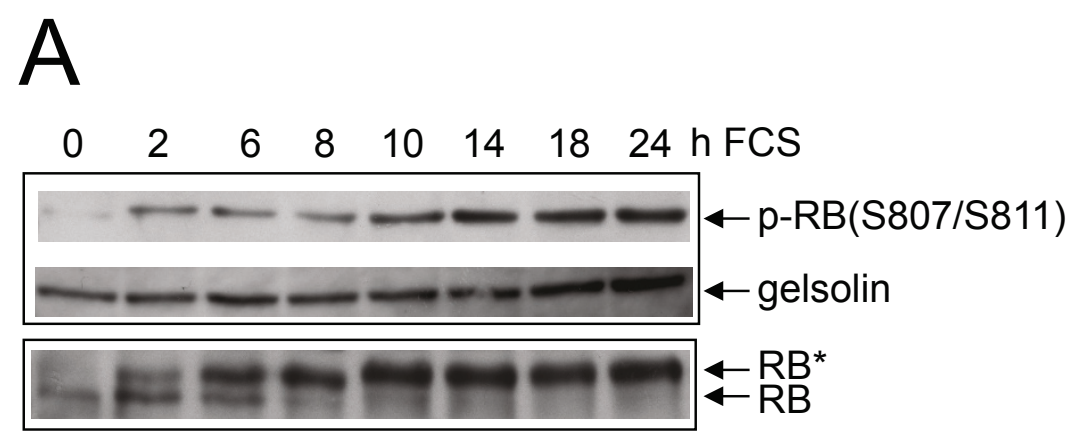

$\mathrm{B}$

$\underline{0} \quad 10 \quad 14 \quad 18 \quad 24 \quad$ h FCS
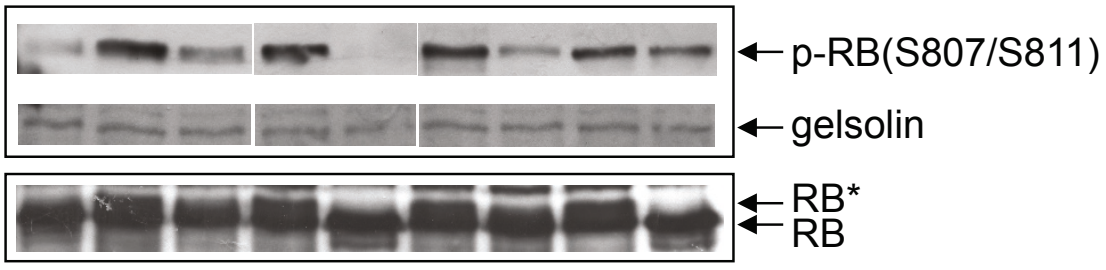

$-\quad-\quad+\quad-\quad+\quad-\quad+\quad+\quad+$ SB203580

0
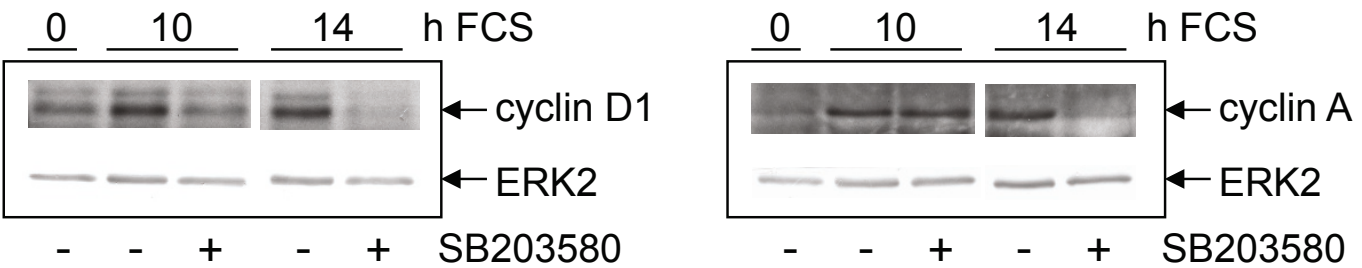

$\mathrm{D}$

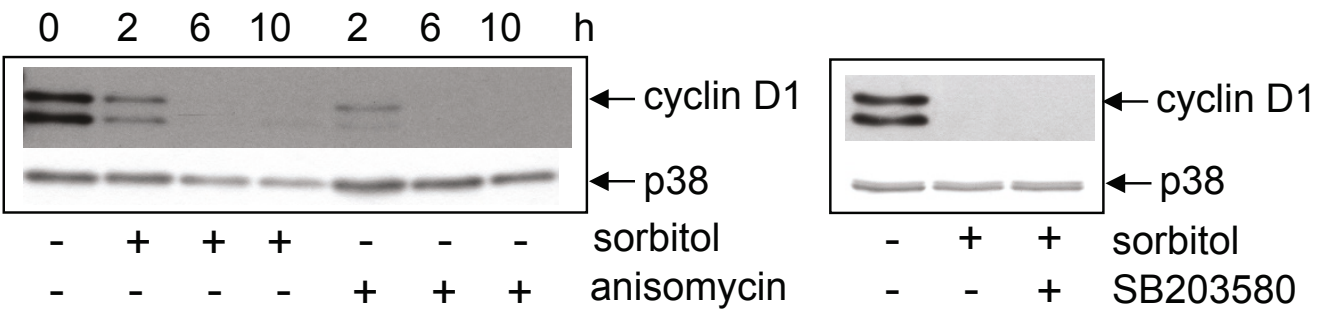

Figure 3 Analysis of cell cycle proteins as potential p38 downstream targets. (A) Serum-starved NIH3T3 cells were stimulated with FCS or (B) stimulated with FCS in the absence or presence of SB203580 for the indicated time points. Western blot analysis was performed using a phospho-specific (S807/S811) anti-pRB-antibody. The blots were stripped and reprobed with anti-gelsolin-antibody to control equal loading. The same samples were loaded and subjected to Western blot analysis using a pRB-antibody. RB* = phosphorylated pRB. (C) Serum-starved NIH3T3 cells were not pretreated or pretreated with SB203580 and then stimulated with FCS for the indicated time points. Western blot analysis was performed using anti-cyclin D1- (left) or anti-cyclin A-antibodies (right). (D) Serum-starved NIH3T3 cells were exposed to anisomycin or sorbitol for the indicated time points (left) or exposed to sorbitol for $6 \mathrm{~h}$ after preincubation with SB203580 (right). Western blot analysis was performed using anti-cyclin D1-antibody. Equal loading was controlled by stripping and reprobing the blots with anti-ERK2-antibody. 
A
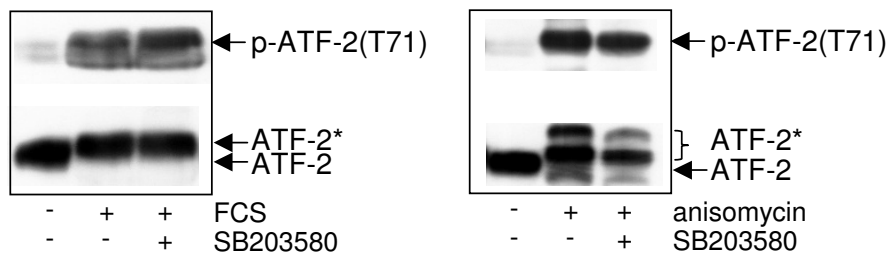

B

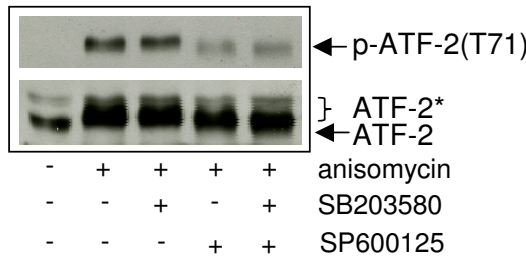

C
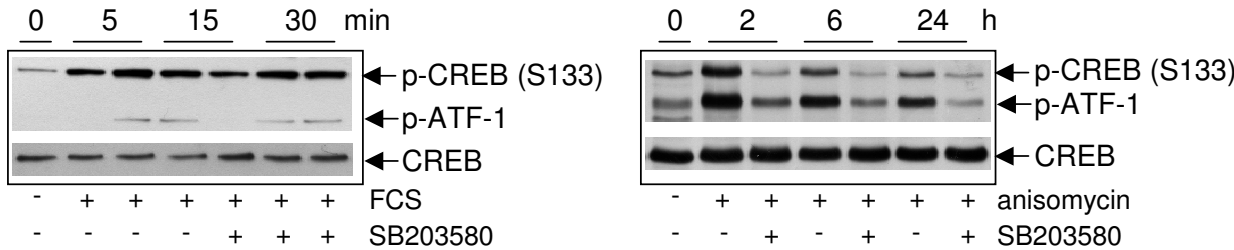

$\mathrm{D}$

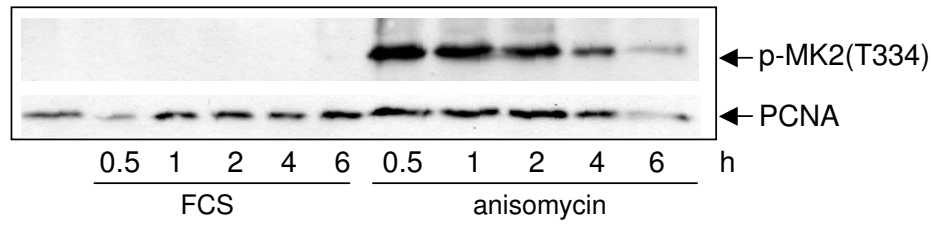

$E$

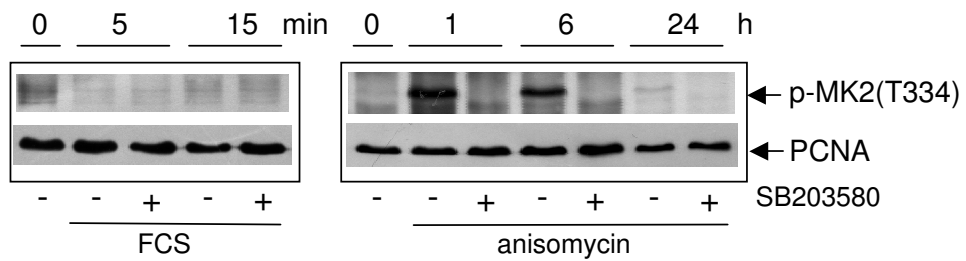

Figure 4 Analysis of p38-mediated substrate phosphorylation. (A) Serum-starved NIH3T3 cells were either not pretreated or pretreated with SB203580. Cells were not stimulated, stimulated with FCS (left) or with anisomycin (right) for 15 min. Total cell extracts were performed and subjected to Western blot analysis. Phosphorylation of ATF-2 was detected using a phospho-specific antibody, equal loading was controlled by stripping and reprobing the blot with anti-ATF-2-antibody. (B) NIH3T3 cells were either not treated or treated with anisomycin in the absence or presence of

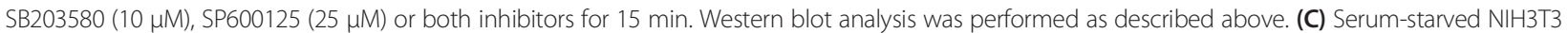
cells were either not pretreated or pretreated with SB203580 and then stimulated with FCS (left) or anisomycin (right) for the indicated time points. Total cell extracts were performed and subjected to Western blot analysis. Phosphorylation of CREB was detected using a phospho-specific antibody, equal loading was controlled by stripping and reprobing the blot with anti-CREB-antibody. The anti-phospho-CREB-antibody also recognizes phosphorylated ATF-1. ATF-2* = phosphorylated ATF-2. (D) Serum-starved NIH3T3 cells were either not treated or treated with FCS or anisomycin for the indicated time points. Western blot analysis was performed using a phospho-specific anti-MK2-antibody. The blot was stripped and reprobed with anti-PCNA-antibody to control equal loading. (E) Serum-starved NIH3T3 cells were either not treated or treated with FCS or anisomycin for the indicated time points in the absence or presence of SB203580 (10 $\mu \mathrm{M})$. Western blot analysis was performed using a phospho-specific anti-MK2antibody. The blot was stripped and reprobed with anti-PCNA-antibody to control equal loading. 


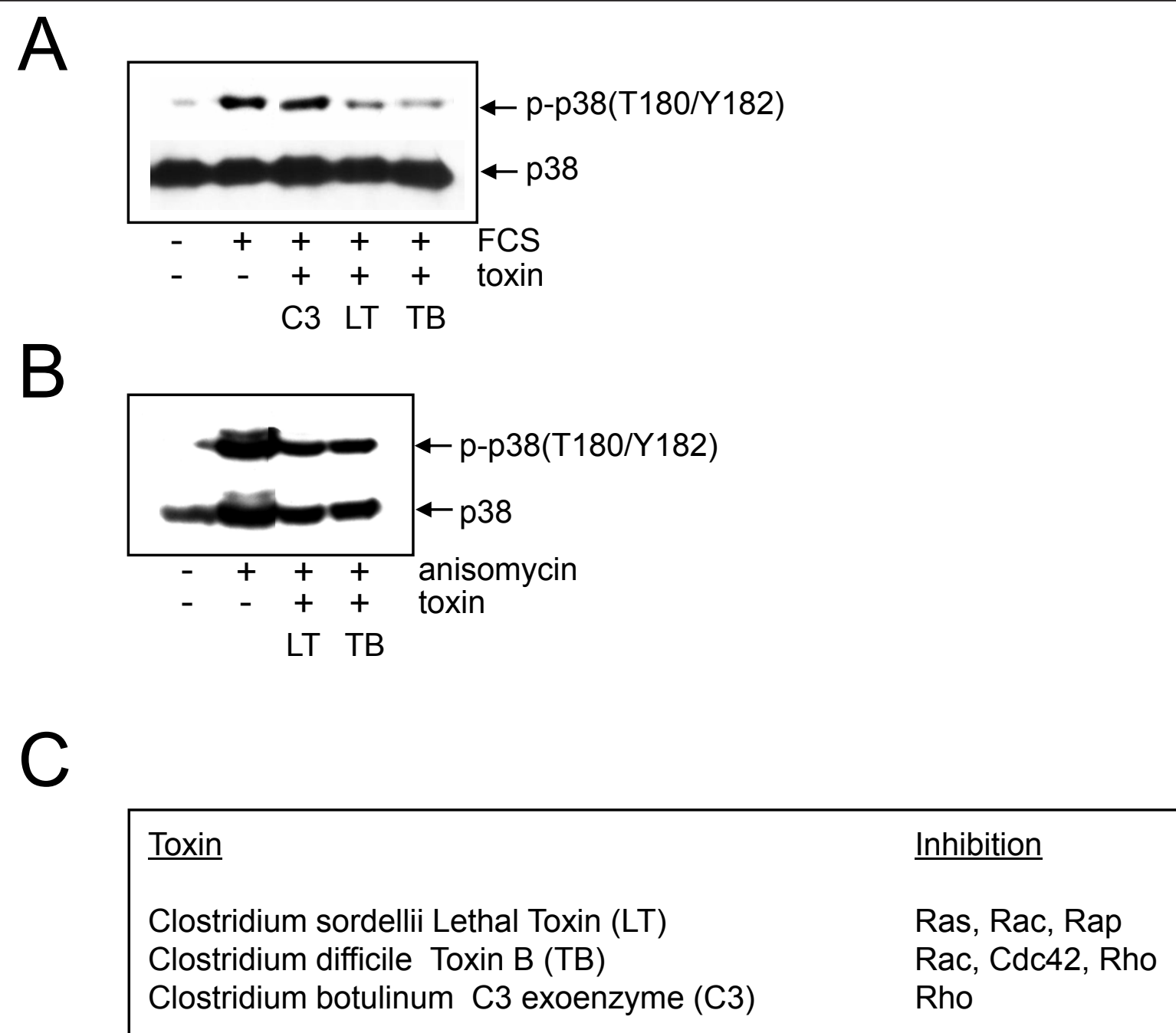

Figure 5 Effect of inhibiting small GTPases by bacterial toxins on p38 phosphorylation. (A, B) Serum-starved NIH3T3 cells were either not pretreated or preincubated for $23 \mathrm{~h}$ with $400 \mathrm{ng} / \mathrm{ml}$ of C2IN-C3 (C3), for $2 \mathrm{~h}$ with $200 \mathrm{ng} / \mathrm{ml}$ of Lethal Toxin (LT), or for $2.5 \mathrm{~h}$ with $10 \mathrm{ng} / \mathrm{ml}$ of Toxin B (TB). Cells were either not stimulated or stimulated for 30 min with FCS (A) or anisomycin (B). Western blot analysis was performed with a phospho-specific anti-p38-antibody followed by reprobing with anti-p38-antibody. (C) Presentation of the bacterial toxins used indicating their substrate specificity according to [29-31].

demonstrated by the fact that ERK phosphorylation in response to FCS, which is downstream of Ras but not the other GTPases, was only blocked by LT but not by TB and C3 (Additional file 6B) [32]. The same was demonstrated in FH109 cells (data not shown). In conclusion, our results strongly argue for an involvement of GTPases in FCS-, but not in anisomycin-induced p38 phosphorylation.

In summary, we propose a hypothetical model for $\mathrm{p} 38$ signalling downstream of distinct stimuli which is depicted in Figure 6. We propose that discrete mechanisms lead to p38 activation after FCS- and anisomycinexposure. Mitogens, but not cellular stress mediated by anisomycin, operate via small GTPases and subsequently trigger p38-dependent regulation of the retinoblastoma pathway. However, stress-induced p38 signalling initiates
MK2 activity and hence phosphorylation of CREB without a concomitant proliferative response.

\section{Discussion}

In the present work we show that p38 is activated by mitogens and cellular stress in the same cell line, but that the signalling pathways differ. We suggest that p38 plays a dual role in cell cycle control in fibroblasts mediating cell cycle progression or cell cycle arrest depending on the extracellular stimulus. In NIH3T3 cells, p38-dependent cell cycle arrest either due to cellular stress or constitutive activation by overexpression of the kinase itself or an upstream activating kinase has been demonstrated in various publications [7-10]. The fact that in the present study in the same cell line stimulation with serum or growth 


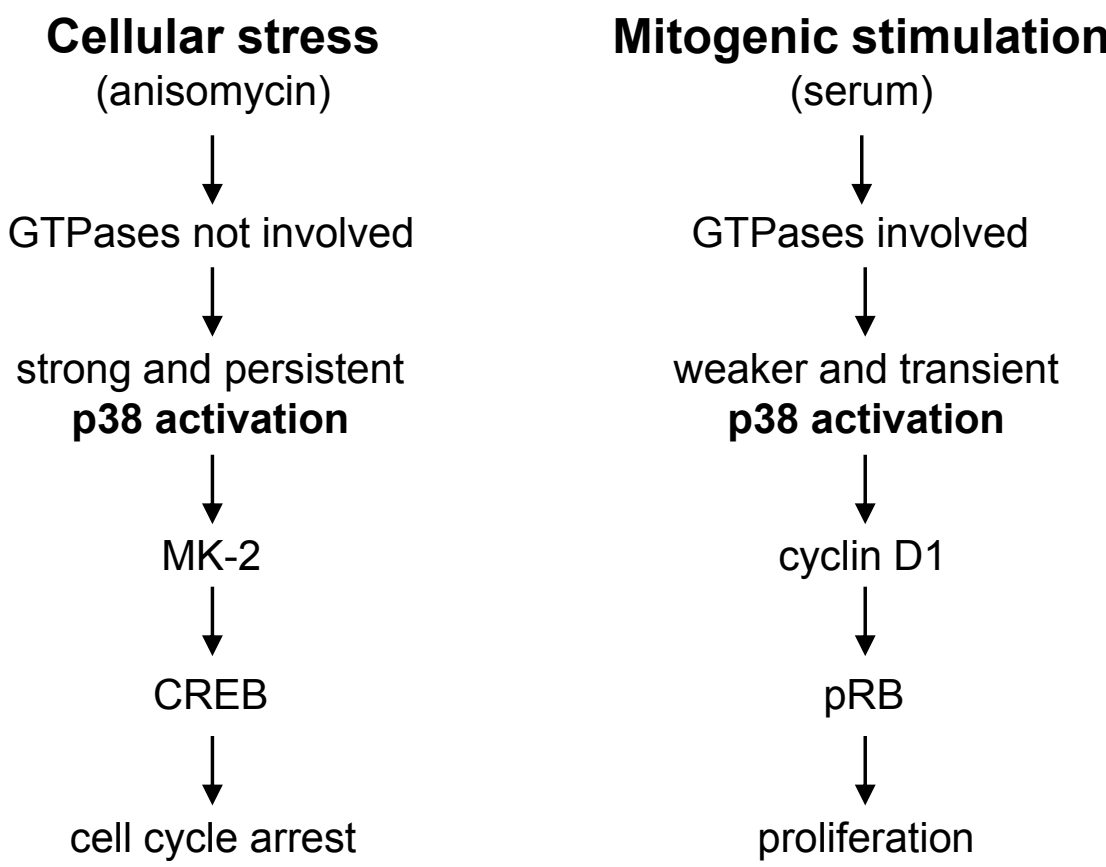

Figure 6 Proposed hypothetical model describing different p38 signalling pathways in response to mitogens and cellular stress. Anisomycin leads to a sustained phosphorylation of p38 which is independent of upstream-acting small GTPases and accompanied by an accumulation of p38 in the nucleus. One downstream substrate of p38 is CREB. In contrast, p38 is transiently phosphorylated after serumstimulation in a GTPase-dependent manner and cyclin D1 is upregulated. The cellular response is proliferation.

factors results in phosphorylation and activation of p38, and - vice versa - FCS- and growth factor-induced DNAsynthesis is blocked by the p38-specific inhibitor SB203580 or siRNA-mediated knock-down of p38 clearly indicates that p38 is also required for proliferation and points to a dual role of $\mathrm{p} 38$ in cell cycle regulation. Our data suggest that a key element might be the duration and/or amount of activation which then leads to different downstream signalling. While anisomycin-exposure leads to a strong and sustained activation of the p38 and MK2 kinases, thereby increasing the phosphorylation of CREB $[27,28]$, mitogen-induced activation of p38 is weaker and transient, but is required for cyclin D1 expression. In addition, we demonstrate that $\mathrm{p} 38$ is differentially regulated in response to anisomycin and mitogens with respect to the involvement of small GTPases (Figure 6).

Dual regulation of a kinase depending on the extracellular stimulus has been proposed in the neuronal cell line PC12 for ERK [for review see [33]]. In these cells, EGF leads to a transient activation of ERK with cytoplasmic retention resulting in a proliferative cellular response. In contrast, NGF-induced ERK activation in the same cells is sustained and accompanied by a nuclear translocation causing cell cycle arrest and neuronal differentiation.

To better understand the role of p38 in mitogeninduced proliferation, we studied cell cycle proteins, i.e. phosphorylation of $\mathrm{pRB}$ and expression of the cyclins D1 and A. It is generally accepted that during G1-phase, cyclin D1/Cdk4 and downstream cyclin E/Cdk2 phosphorylate $\mathrm{pRB}$ which then dissociates from the transcription factor E2F allowing transcription of S-phase specific genes, such as cyclin A, and thereby entry into S-phase [24]. Since the mitogen-induced expression of cyclin D1 was strongly reduced in the presence of SB203580 we conclude that expression of cyclin D1 requires the activity of p38. An expected consequence of a decrease in cyclin D1 is less activity of the cyclin D1/Cdk4 complex and in turn less phosphorylation of $\mathrm{pRB}$. Hence, the observed attenuation of $\mathrm{pRB}$ phosphorylation in the presence of SB203580 is very likely due to decreased cyclin D1 expression. Downregulation of cyclin A by SB203580 was observed at a later time point, i.e. $14 \mathrm{~h}$ after mitogenic stimulation. According to the kinetics of pRB phosphorylation we assume that this time point correlates with early S-phase. We therefore conclude that the decrease in cyclin A is not directly mediated by $\mathrm{p} 38$, but rather a consequence of inhibition of $\mathrm{pRB}$ phosphorylation by SB203580.

The mechanism of p38-dependent expression of cyclin D1 in our cell system is not known so far. In melanoma cells, p38-ATF-2-dependent expression of cyclin D1 in response to hepatocyte growth factor/scatter factor has been described [18]. Induction of cyclin D1 by pp60 ${ }^{\mathrm{v}-s r c}$ is also mediated via the p38/JNK-ATF-2/CREB pathway 
in human breast cancer cells [34]. Since we did not detect p38-dependent phosphorylation of ATF-2 nor CREB, an involvement of ATF-2 or CREB in cyclin D1 expression in our cell system is unlikely. One possible explanation comes from the observation, that ERK1/2 phosphorylation is blocked from $6 \mathrm{~h}$ on after FCS-stimulation, very likely as a secondary effect of p38 inhibition. Hence, p38 activity seems to be required for sustained ERK1/2 phosphorylation. In fibroblasts, sustained ERK1/2 activity is required for cyclin D1 expression, especially during midG1-phase [35]. The underlying mechanism of this crosstalk between p38 and ERK1/2 remains to be elucidated.

To our surprise, inhibition of p38 function by SB203580 did not only block mitogen-induced G0/G1-S transition, but also attenuated continuous proliferation of NIH3T3 cells. This observation is in contrast to data obtained in BJ primary fibroblasts and WI-38 fibroblasts. In these cells, SB203580 does not alter proliferation in exponentially growing cultures, which show doubling rates comparable to our NIH3T3 [36,37]. However, cell type specific differences might explain different functions of p38 in NIH3T3 cells. Very recently, it was shown that the transcription factor FoxM1 acts downstream from the Ras-MKK3-p38 pathway in NIH3T3 cells [38]. Importantly, FoxM1 is also known to regulate a number of proliferative genes [38; manuscript in preparation]. Although we have not tested, another explanation for the discrepancies could be p53 function. While BJ and WI-38 fibroblast express wild-type p53 $[39,40]$, the NIH3T3 cells we used are p53-deficient (unpublished observations).

Our observation of a sustained p38 activation after anisomycin- or sorbitol-treatment is in accordance with other reports showing persistent activation of p38 after cellular stress, e.g. in $\mathrm{C} 3 \mathrm{H} 10 \mathrm{~T} 1 / 2$ cells in response to anisomycin or UV [41] or in several cell lines in response to $\gamma$-irradiation, genotoxic compounds or during premature senescence [[42,43], reviewed in [6]].

We have also shown that sustained activation of p38 is required for contact-inhibition in murine and human fibroblasts [12]. Several mechanisms explaining p38dependent cell cycle arrest have been described. For instance, $\mathrm{p} 27^{\mathrm{KIP} 1}$, a well-known inhibitor of Cdk2 and $\mathrm{Cdk} 4$, is one important downstream target of p38 upon contact-inhibition $[12,44]$. The protein $\mathrm{p} 27^{\mathrm{KIP} 1}$ is also upregulated in response to genotoxic agents and here is supposed to be crucial for maintenance of cell cycle arrest [43]. However, we did not observe accumulation of $\mathrm{p} 27^{\mathrm{KIP} 1}$ in response to anisomycin or sorbitol (unpublished oberservation). It is also known that the Cdk inhibitors $\mathrm{p} 21^{\mathrm{WAF} 1 / \mathrm{CIP} 1}$ and $\mathrm{p} 16^{\mathrm{INK} 4 \mathrm{a}}$ mediate $\mathrm{p} 38$-dependent senescence, for instance in response to DNA-damaging agents and reactive oxygen species, which might be related to the role of p38 as a tumour suppressor [42,45-51]. Very recently, p38-dependent induction of p21 due to sorbitoltreatment has been described in nucleus pulposus intervertebral disc cells [52]. Whether p $21^{\text {WAF1/CIP1 }}$ or $\mathrm{p} 16^{\mathrm{INK} 4 \mathrm{a}}$ are upregulated in response to anisomycin or sorbitol in fibroblasts needs to be determined.

Moreover, we observed sustained phosphorylation of CREB. Two kinases are known to phosphorylate this transcription factor: MK2 [27,28] and MSK1 [26]. Since MK2 was also persistently activated in response to anisomycin, we conclude that MK2 at least partially contributes to phosphorylation of CREB. A possible involvement of MSK1 remains to be elucidated. Interestingly, cell cycle arrest due to sustained activation of the cAMP/CREBpathway was also detected in prostate carcinoma cells, which were chronically exposed to pituitary adenylatecyclase-activating polypeptide. In contrast, transient stimulation of cAMP/CREB induces proliferation [53]. Constitutive activation of CREB by bacterial toxins leads to G1-arrest in a murine macrophage cell line by induction of p27 and downregulation of cyclin D1 [54]. In accordance, cholera toxin, a potent inducer of cellular accumulation of cAMP and thereby phosphorylation of CREB, is able to cause G1 arrest by upregulation of p27, p21 and downregulation of cyclin D1 in rat and primary human glioma cells [55]. However, we could not reverse downregulation of cyclin D1 in response to sorbitol-exposure by SB203580 arguing that p38 is not the sole entity responsible for the decrease in cyclin D1. This is in line with the observation that arsenite-induced downregulation of cyclin D1 in NIH3T3 cells cannot be restored by SB203580 [8] and that cyclin D1 decrease can also be mediated by JNK [56]. Hence, the precise function of the p38-MK2-CREB axis in anisomycin- or sorbitol-induced cell cycle arrest remains to be determined.

Phosphorylation of CREB in response to mitogenic stimulation could not be blocked by SB203580, which is in line with previous observations that CREB phosphorylation in response to growth factors is mediated by the ERK pathway [26].

Interestingly, phosphorylation of ATF-2 was not inhibited by SB203580, although it has been identified to be an excellent substrate for p38 in vitro [25]. This observation is in perfect accordance with the work of Hazzalin and coworkers [41] and the work by Maher [13] ruling out involvement of p38 in phosphorylating endogenous ATF-2 in fibroblasts. Since phosphorylation of ATF-2 could be blocked by pharmacological inhibition of JNK, phosphorylation of ATF-2 is very likely dependent on JNK [57].

Persistent activation after anisomycin is consistent with the supposed mechanism of action: anisomycin inhibits protein synthesis hence blocking transcription of phosphatases. As a result, p38 dephosphorylation does not occur in the presence of anisomycin. Furthermore, dephosphorylation of the upstream acting MKK3/6 is 
inhibited thereby allowing prolonged activation of p38. A similar mechanism has been described for arseniteinduced JNK activation $[58,59]$. To gain more insight into upstream events regulating p38 activity in response to mitogens, we identified the involvement of small GTPases and made use of selective bacterial toxins. Clostridium sordellii Lethal Toxin (LT) inhibits Ras, Rac, and Rap function, Clostridium difficile Toxin B abolishes Rac, Cdc42, and Rho function, and Botulinus C3 exoenzyme, in our study used as C2IN-C3 fusion toxin displaying high cell permeability [60], selectively inhibits Rho function $[29,30]$. The observation, that ERK activation was selectively abolished only in the presence of Lethal Toxin indicates selectivity of the toxins. In control experiments with Botulinus $\mathrm{C} 2$ toxin, which ADP-ribosylates actin [29], we ruled out that the observed inhibitory effects of the toxins occurred unspecifically due to degradation of the actin cytoskeleton (unpublished observation). If anisomycin-induced p38 activation is due to its suppression of phosphatases (see above) it should be independent of Rho proteins. Indeed, blocking the activity of the small GTPases Rho, Rac, and Cdc42 by preincubation with Lethal Toxin or Toxin B, had no effect on anisomycininduced p38 phosphorylation.

On the contrary, serum-induced p38 activation could be blocked by preincubation with Toxin B and Lethal Toxin. In view of the fact that $\mathrm{C} 2 \mathrm{IN}-\mathrm{C} 3 \mathrm{had}$ no effect on seruminduced p38 phosphorylation, the results strongly argue against an involvement of Rho and point to a potential role of Rac and/or Ras and Cdc42. Indeed, in overexpression studies, Rac and Cdc42 have been identified to mediate p38 activation $[10,61,62]$. More detailed analysis is required to identify which of the small GTPases is involved in p38-mediated control of proliferation.

\section{Conclusions}

We present a novel hypothetical model for p38 function and propose a dual role of p38 activation in cell cycle control. Cellular stress by anisomycin leads to a sustained phosphorylation and activation of p38. One downstream substrate of p38 is MK2 which phosphorylates CREB. In contrast, after mitogenic stimulation p38 is only transiently phosphorylated, but promotes cyclin D1 expression. The cellular response is proliferation. Differential target activation by $\mathrm{p} 38$ downstream of mitogenic and stress signals might be related to the respective strength or duration of p38 activation or, alternatively, to additional cross-talk with parallel pathways - an issue which warrants further investigations.

\section{Materials and methods \\ Cell culture}

FH109 human embryonal lung fibroblasts [63] and NIH3T3 murine fibroblasts were routinely cultured in
Dulbecco's Modified Eagle's Medium (DMEM) (PAA), supplemented with $10 \%$ fetal calf serum (FCS) (PAA), 4 $\mathrm{mM}$ glutamine, penicillin and streptomycin (each $100 \mathrm{U} /$ $\mathrm{ml}$ ). For experiments, FH109 or NIH3T3 cells were cultured in DMEM/0.2\% FCS for $72 \mathrm{~h}$ and then treated with anisomycin $(10 \mu \mathrm{g} / \mathrm{ml})$ (Sigma) or FCS to a final concentration of $10 \%$ and harvested at different time points as described in the figure legends. Cells were pretreated with SB203580 (10 $\mu \mathrm{M})$ (Calbiochem), or SP600125 (25 $\mu \mathrm{M})$ (Enzo Life Sciences), control cells were exposed to $0.1 \%$ DMSO, the solvent used for the inhibitors.

\section{Measurement of DNA-synthesis}

FH109 or NIH3T3 cells were seeded into microtiter plates at a density of $8 \times 10^{3} /$ well or $5 \times 10^{3} /$ well, respectively, and cultured for $72 \mathrm{~h}$ in DMEM/0.2\% FCS. Cells were stimulated for $24 \mathrm{~h}$ by the addition of $10 \%$ FCS, PDGF- or bFGF (each $50 \mathrm{ng} / \mathrm{ml}$, Cell Signaling). SB203580 was added $1 \mathrm{~h}$ before stimulation. DNA-synthesis was measured by $\left[{ }^{3} \mathrm{H}\right]$ thymidine-incorporation as described [64].

\section{Determination of cell number}

Cells were washed, trypsinised and counted in a hemocytometer.

\section{Western blotting}

Total cell extracts were prepared by lysing the cells in hot Laemmli sample buffer and protein concentration was determined according to [65]. Equal amounts of protein (20 - $50 \mu \mathrm{g}$ protein/lane) were separated by SDS-PAGE (7.5 - 10\%) and electroblotted overnight onto Immobilon membrane (Millipore). The membranes were blocked for $1 \mathrm{~h}$ with $5 \%$ low-fat milk-powder or $5 \%$ bovine serum albumin in TBS (50 mM Tris- $\mathrm{HCl}, \mathrm{pH} 7.5,150 \mathrm{mM} \mathrm{NaCl}$ ) containing $0.05 \%$ Tween 20 and then incubated either for $1.5 \mathrm{~h}$ at room temperature with anti-cyclin D1-, anti-cyclin A - (1:1000, Santa Cruz), or overnight at $4^{\circ} \mathrm{C}$ with antiphospho-pRb- (1:1000, Cell Signaling), anti-phospho-p38-, anti-CREB, anti-phospho-ATF-2-, anti-phospho-c-Jun-, or anti-phospho-MK2-antibody (1:1000-2000, Cell Signaling) followed by incubation with horseradish-peroxidase-conjugated secondary antibody and ECL-detection according to the manufacturer's instructions. The blots were stripped and reprobed with anti-p38 $\alpha$-, anti-phospho-CREB-, (1:1000, Cell Signaling), anti-ATF-2-, anti-PCNA-, antiERK-, or anti-c-Jun-antibody (1:1000, Santa Cruz) or antigelsolin-antibody (1:200, Santa Cruz) followed by ECL-detection.

\section{Transfection of siRNA}

For transient transfection of p38 $\alpha$ or control siRNA, $5 \times$ $10^{3}$ cells/well (96 well plate) were seeded and cultured for $24 \mathrm{~h}$ to reach $80-90 \%$ confluence. Transfection was performed in a total volume of $120 \mu \mathrm{l}$ containing 8 
pmol siRNA and $0.2 \mu \mathrm{l}$ of Lipofectamine 2000 according to the manufacturer's instructions. After $24 \mathrm{~h}$, medium was changed to DMEM/0.2\% FCS and the cells cultured for another $24 \mathrm{~h}$. Cells were then exposed for $24 \mathrm{~h}$ to PDGF $\beta$ or bFGF (see above) and incorporation of $\left[{ }^{3} \mathrm{H}\right]$ thymidine was determined. p38 $\alpha$ siRNA (directed against murine p38 $\alpha$ mRNA sequence [MGI:1346865]): 5'-GGAAUUCAAUGACGUGU AC-3'; control siRNA (directed against mRNA encoding the red fluorescence protein DsRed from the coral Discosoma) has been published previously [66].

\section{Additional material}

Additional file 1: Effect of impairment of p38 function on mitogeninduced DNA synthesis. Serum-starved FH109 cells were either not pretreated or preincubated for $1 \mathrm{~h}$ with SB203580 $(10 \mu \mathrm{M})$. The cells were then stimulated with $10 \%$ FCS, PDGF $\beta$, bFGF (each $50 \mathrm{ng} / \mathrm{ml}$ ) or EGF $(100 \mathrm{ng} / \mathrm{ml})$ for $20 \mathrm{~h}$ and labelled with [3H]thymidine for additional $4 \mathrm{~h}$. Incorporated radioactivity was determined by liquid scintillation spectrometry. Results are given as $\mathrm{x}$-fold induction of $\left[^{3} \mathrm{H}\right]$ thymidine incorporation compared to unstimulated, serum-starved cells and are the average $\pm S x$ of a number of four for each run of treatment. The results represent one out of three independent experiments each leading to similar results.

Additional file 2: Specificity of SB203580-treatment and siRNAmediated knock-down of p38. (A, B) NIH3T3 cells were transiently transfected with siRNA directed against p38 $\alpha$ or with control siRNA. $24 \mathrm{~h}$ after transfection, cells were serum-starved and cultured for another $24 \mathrm{~h}$. Cells were then stimulated with PDGF $\beta(50 \mathrm{ng} / \mathrm{ml})($ A) or bFGF $(50 \mathrm{ng} /$ $\mathrm{ml}$ (B) for the indicated time points. Western blot was performed using a monoclonal phospho-specific anti-p38-antibody. In parallel, the same samples were subjected to Western blot analysis using anti-p38-antibody. The blot was stripped and incubated with a monoclonal anti-phosphoERK1/2-antibody. The blot was stripped again and subjected to immunoblotting using an ERK2-antibody to control equal loading. (C) Serum-starved $\mathrm{NIH} 3 \mathrm{~T} 3$ cells were treated with FCS in the absence or presence of SB203580 $(10 \mu \mathrm{M})$ for the indicated time points. Western blot analysis was performed using anti-phospho-ERK1/2-antibody. Blots were stripped and reprobed with anti-ERK2-antibody to control equal loading. (D) NIH3T3 cells were not stimulated or stimulated with anisomycin in the absence or presence of SB203580 (10 $\mu \mathrm{M})$, SP600125 $(25 \mu \mathrm{M})$ or both inhibitors for the indicated time points. Western blot analysis was performed using a phospho-specific anti-c-Jun-antibody. Blots were stripped and reprobed with anti-c-Jun-antibody to control equal loading.

Additional file 3: Stimulation of $\mathrm{p} 38$ by mitogens and cellular stress Serum-starved FH109 cells were treated with FCS (A), or anisomycin (10 $\mathrm{\mu g} / \mathrm{ml})(B)$ and total cell extracts prepared at the indicated time points. Western Blot analysis was performed using a phospho-specific (T180/ Y182) anti-p38-antibody. The blots were stripped and reprobed with an anti-p38-antibody to control equal loading. Data from a single experiment are shown. Similar results were obtained in three independent experiments. (C) Serum-starved FH109 cells were untreated or stimulated with FCS or anisomycin for 30 min. Kinase activity was measured after immunoprecipitation with a monoclonal phosphospecific anti-p38-antibody and ATF-2 fusion protein as substrate. Phosphorylation of ATF-2 was determined by Western blot analysis with a phospho-specific anti-ATF-2-antibody.

Additional file 4: Serum-starved NIH3T3 (A) or FH109 (B) cells were not pretreated or pretreated with SB203580 and then stimulated with FCS for the indicated time points. Western blot analysis was performed using anti-cyclin D1- (A, B) or anti-cyclin A-antibodies (B). Additional file 5: Analysis of p38 kinase mediated substrate phosphorylation. Serum-starved FH109 cells were either not treated or pretreated with SB203580. (A, B) Cells were not stimulated, or stimulated either with FCS (A) or anisomycin (B) for 15 min. Total cell extracts were performed and subjected to Western blot analysis. Phosphorylation of CREB and ATF-2 was detected using phospho-specific antibodies, equal loading was controlled by anti-CREB- and anti-ATF-2-antibodies. The antiphospho-CREB-antibody also recognizes phosphorylated ATF-1. ATF-2* $=$ phosphorylated ATF-2 (C) Serum-starved FH109 cells were either not treated or stimulated with anisomycin and cell extracts prepared at the indicated time points. Western blot analysis for detection of CREB phosphorylation was performed as described above.

Additional file 6: Inhibition of small GTPases by bacterial toxins characteristically deregulates actin cytoskeleton and ERK1/2phosphorylation. Serum-starved NHH3T3 cells were either not pretreated or preincubated for $23 \mathrm{~h}$ with $400 \mathrm{ng} / \mathrm{ml}$ of $\mathrm{C} 2 \mathrm{IN}-\mathrm{C} 3$ (C3), for $2 \mathrm{~h}$ with $200 \mathrm{ng} / \mathrm{ml}$ of Lethal Toxin (LT), or for $2.5 \mathrm{~h}$ with $10 \mathrm{ng} / \mathrm{ml}$ of Toxin B (TB). (A) FITC-phalloidin staining to visualise activity of the bacterial toxins. As expected, exposure to $\mathrm{C} 3$ induces depolymerisation of actin stress fibres with little effect on lamellipodia or filopodia, TB strongly depolymerises the actin cytoskeleton [31], and LT causes rounding of cell bodies and disruption of actin stress fibres [32]. (B) Cells were either not stimulated or stimulated for 30 min with FCS. Western blot analysis was performed with anti-ERK1/2-antibody. As already shown by [32], LT inhibits phosphorylation of ERK1/2. ERK1*/ERK2* ${ }^{*}$ phosphorylated ERK1/ERK2.

\section{Acknowledgements}

We are indebted to H. Barth, F. Hofmann and K. Aktories for the generous gifts of the bacterial toxins. The work was supported by the grant Di793/1-1 from the Deutsche Forschungsgemeinschaft and by ECNIS (Environmental Cancer Risk, Nutrition and Individual Susceptibility), a network of excellence operating within the European Union $6^{\text {th }}$ Framework program, Priority 5: 'Food Quality and Safety' (Contract no. 513943) and is part of the M.D. thesis of C.S.

\section{Author details}

'Institute of Toxicology, Medical Center of the Johannes GutenbergUniversity, Obere Zahlbacherstr. 67, 55131 Mainz, Germany. ${ }^{2}$ Institute of Toxicology and Genetics, Karlsruhe Institute of Technology, Campus North, Hermann-von-Helmholtz-Platz 1, Eggenstein-Leopoldshafen, Germany.

\section{Authors' contributions}

DF, CS and IS performed the experiments, CW and CD designed the experiments, CD wrote the paper, CW, FO and BO critically revised the manuscript. All authors read and approved the final manuscript.

\section{Competing interests}

The authors declare that they have no competing interests.

Received: 14 September 2011 Accepted: 9 March 2012 Published: 9 March 2012

\section{References}

1. Kyriakis J, Avruch J: Protein kinase cascades activated by stress and inflammatory cytokines. Bioessays 1996, 18:567-577.

2. Junttila MR, Li S-P, Westermarck J: Phosphatase-mediated crosstalk between MAPK signaling pathways in the regulation of cell survival. FASEB J 2008, 22:954-964

3. Herlich P, Karin M, Weiss C: Supreme EnLIGHTenment: damage recognition and signaling in the mammalian UV response. Mol Cell 2008, 29:279-290.

4. Cuadrado A, Nebreda AR: Mechanisms and functions of p38 MAPK signalling. Biochem J 2010, 429:403-417.

5. Han J, Lee J-D, Bibbs L, Ulevitch RJ: A MAP kinase targeted by endotoxin and hyperosmolarity in mammalian cells. Science 1994, 265:808-811.

6. Han J, Sun P: The pathways to tumor suppression via route p38. Trends Biochem Sci 2007, 32:364-371.

7. Wang $X Z$, Ron D: Stress-induced phosphorylation and activation of the transcription factor CHOP (GADD153) by p38 MAP kinase. Science 1996, 272:1347-1349. 
8. Kim JY, Choi JA, Kim TH, Yoo YD, Kim Jl, Lee YJ, Yoo SY, Cho CK, Lee YS, Lee SJ: Involvement of p38 mitogen-activated protein kinase in the cell growth inhibition by sodium arsenite. J Cell Physiol 2002, 190:29-37.

9. Chen G, Hitomi M, Han J, Stacey DW: The p38 pathway provides negative feedback for Ras proliferative signaling. J Biol Chem 2000, 275:38973-38980.

10. Molnar A, Theodoras A, Zon L, Kyriakis J: Cdc42Hs, but not rac1, inhibits serum- stimulated cell cycle progression at G1/S through a mechanism requiring p38/RK. J Biol Chem 1997, 272:13229-13235.

11. Puri PL, Wu Z, Zhang P, Wood LD, Bhakta KS, Han J, Feramisco JR, Karin M, Wang JYJ: Induction of terminal differentiation by constitutive activation of p38 MAP kinase in human rhabdomyosarcoma cells. Genes Dev 2011, 14:574-584.

12. Faust D, Dolado I, Cuadrado A, Oesch F, Weiss C, Nebreda AR, Dietrich C: p38alpha MAPK is required for contact inhibition. Oncogene 2005, 24:7941-7945.

13. Maher P: p38 mitogen-activated protein kinase activation is required for fibroblast growth factor-2-stimulated cell proliferation but not differentiation. J Biol Chem 1999, 274:17491-17498.

14. Dixon M, Agius L, Yeaman SJ, Day CP: Inhibition of rat hepatocyte proliferation by transforming growth factor beta and glucagon is associated with inhibition of ERK2 and p70 S6 kinase. Hepatology 1999, 29:1418-1424.

15. Rausch O, Marshall C: Cooperation of p38 and extracellular signalregulated kinase mitogen-activated protein kinase pathways during granulocyte colony-stimulating factor-induced hemopoietic cell proliferation. J Biol Chem 1999, 274:4096-4105.

16. Chen L, Mayer JA, Krisko TI, Speers CW, Wang T, Hilsenbeck SG, Brown PH: Inhibition of the p38 kinase suppresses the proliferation of human ERnegative breast cancer cells. Cancer Res 2009, 69:8853-8861.

17. Halawani D, Mondeh R, Stanton LA, Beier F: p38 MAP kinase signaling is necessary for rat chondrosarcoma cell proliferation. Oncogene 2004 23:3726-3731.

18. Recio JA, Merlino G: Hepatocyte growth factor/scatter factor activates proliferation in melanoma cells through p38 MAPK, ATF-2 and cyclin D1. Oncogene 2002, 21:1000-1008.

19. Cuenda A, Rouse J, Doza Y, Meier R, Cohen P, Gallagher T, Young P, Lee J: SB203580 is a specific inhibitor of a MAP kinase homologue which is stimulated by cellular stresses and interleukin-1. FEBS Lett 1995 364:229-233.

20. Behren A, Binder K, Vucelic G, Herberhold S, Hirt B, Loewenheim H, Preyer S, Zenner HP, Simon C: The p38 SAPK pathway is required for Haras induced in vitro invasion of NIH3T3 cells. Exp Cell Res 2005, 303:321-330

21. Bain J, Plater L, Elliot M, Shpiro N, Hastie J, McLaughlan H, Klevernic I, Arthur JSC, Alessi DR, Cohen P: The selectivity of protein kinase inhibitors: a further update. Biochem J 2007, 408:297-315.

22. Raingeaud J, Whitmarsh A, Barrett T, Derijard B, Davis R: MKK3- and MKK6regulated gene expression is mediated by the p38 mitogen-activated protein kinase signal transduction pathway. Mol Cell Biol 1996, 16:1247-1255.

23. Ono K, Han J: The p38 signal transduction pathway Activation and function. Cell Signal 2000, 12:1-13.

24. Malumbres M, Barbacid M: Mammalian cyclin-dependent kinases. Trends Biochem Sci 2005, 30:630-641

25. Raingeaud J, Gupta S, Rogers J, Dickens M, Han J, Ulevitch RJ, Davis R: Proinflammatory cytokines and environmental stress cause p38 mitogenactivated protein kinase activation by dual phosphorylation on tyrosine and threonine. J Biol Chem 1995, 270:7420-7426.

26. Deak M, Clifton A, Lucocq J, Alessi D: Mitogen- and stress-activated protein kinase-1 (MSK1) is directly activated by MAPK and SAPK2/p38, and may mediate activation of CREB. EMBO J 1998, 17:4426-4441.

27. Tan Y, Rouse J, Zhang A, Cariati S, Cohen P, Comb M: FGF and stress regulate CREB and ATF-1 via a pathway involving p38 MAP kinase and MAPKAP-K2. EMBO J 1996, 15:4629-4642.

28. Iordanov M, Bender K, Ade T, Schmid W, Sachsenmaier C, Engel K Gaestel M, Rahmsdorf HJ, Herrlich P: CREB is activated by UVC through a p38/HOG-1- dependent protein kinase. EMBO J 1997, 16:1009-1022.

29. Aktories K: Rho proteins: targets for bacterial toxins. TiMB 1997, 5:282-288.

30. Aktories K, Barbieri JT: Bacterial cytotoxins: targeting eukaryotic switches. Nat Rev Microbiol 2005, 3:397-410.
31. Barbieri JT, Riese MJ, Aktories $\mathrm{K}$ : Bacterial toxins that modify the actin cytoskeleton. Annu Rev Cell Dev Biol 2002, 18:315-344.

32. Popoff MR, Chaves-Olarte E, Lemichez E, von Eichel-Streiber C, Thelestam M, Chardin P, Cussac D, Antonny B, Chavrier P, Flatau G, Giry M, de Gunzburg J, Boquet P: Ras, Rap, and Rac small GTP-binding proteins are targets for Clostridium sordellii lethal toxin glucosylation. J Biol Chem 1996, 271:10217-10224

33. Marshall C: Specificity of receptor tyrosine kinase signaling: transient versus sustained extracellular signal-regulated kinase activation. Cell 1995, 80:179-185.

34. Lee RJ, Albanese C, Stenger RJ, Watanabe G, Inghirami G, Haines GK, Webster M, Muller WJ, Brugge JS, Davis RJ, Pestell RG: pp 60(v-src) induction of cyclin D1 requires collaborative interactions between the extracellular signal-regulated kinase, p38, and Jun kinase pathways. A role for CAMP response element-binding protein and activating transcription factor- 2 in pp60(v-src) signaling in breast cancer cells. J Biol Chem 1999, 274:7341-7350

35. Villanueva J, Yung Y, Walker JL, Assoian RK: ERK activity and G1 phase progression: identifying dispensable versus essential activities and primary versus secondary targets. Mol Biol Cell 2007, 18:1457-1463.

36. Wang W, Chen JX, Liao R, Deng Q, Zhou J, Huang S, Sun P: Sequential activation of the MEK-extracellular signal-related kinase and MKK3/6-p38 mitogen-activated protein kinase pathways mediates oncogenic rasinduced premature senescence. Mol Cell Biol 2002, 22:2289-3403.

37. Iwasa $H$, Han J, Ishikawa F: Mitogen-activated protein kinase p38 defines the common senescence-signalling pathway. Genes Cells 2003, 8:131-144

38. Behren A, Mühlen S, Acuna Sanhueza GA, Schwager C, Plinkert PK, Huber PE, Abdollahi A, Simon C: Phenotype-assisted transcriptome analysis identifies foxm 1 downstream from ras-MKK3-p38 to regulate in vitro cellular invasion. Oncogene 2010, 29:1519-1530.

39. Halasi M, Schraufnagel DP, Gartel AL: Wild-type p53 protects normal cells against apoptosis induced by thiostrepton. Cell Cycle 2009, 8:2850-2851.

40. Bhana S, Hewer A, Phillips DH, Lloyd DR: p53-dependent global nucleotide excision repair of cisplatin-induced intrastrand cross links in human cells. Mutagenesis 2008, 23:131-136.

41. Hazzalin C, Cano E, Cuenda A, Barratt M, Cohen P, Mahadevan L: p38/RK is essential for stress-induced nuclear responses: JNK/SAPKs and c-jun/ATF2 phosphorylation are insufficient. Curr Biol 1996, 6:1028-1031.

42. Lafarga V, Cuadrado A, Lopez de Silanes I, Bengoechea R, FernandezCapetillo O, Nebreda AR: p38 Mitogen-activated protein kinase- and HuRdependent stabilization of p21(Cip1) mRNA mediates the $\mathrm{G}(1) / \mathrm{S}$ checkpoint. Mol Cell Biol 2009, 29:4341-4351.

43. Cuadrado M, Gutierrez-Martinez P, Swat A, Nebreda AR, FernandezCapetillo O: p27Kip1 stabilization is essential for the maintenance of cell cycle arrest in response to DNA damage. Cancer Res 2009, 69:8726-8732

44. Swat A, Dolado I, Rojas JM, Nebreda AR: Cell density-dependent inhibition of epidermal growth factor receptor signaling by p38alpha mitogenactivated protein kinase via Sprouty2 downregulation. Mol Cell Biol 2009, 29:3332-3343.

45. Luo Y, Zou P, Zou J, Wang J, Zhou D, Liu L: Autophagy regulates ROSinduced cellular senescence via p21 in a p38 MAPKa dependent manner. Exp Gerontol 2011, 46:860-867.

46. Rudolf $E$, Cervinka M: Stress responses of human dermal fibroblasts exposed to zinc pyrithione. Toxicol Lett 2011, 204:164-173.

47. Nakagawa H, Hirata Y, Takeda K, Hayakawa Y, Sato T, Kinoshita H, Sakamoto K, Nakata W, Hikiba Y, Omata M, Yoshida H, Koike K, Ichijo H, Maeda S: Apoptosis signal-regulating kinase 1 inhibits hepatocarcinogenesis by controlling the tumor- suppressing function of stress-activated mitogen-activated protein kinase. Hepatology 2011, 54:185-195.

48. Shao L, Li H, Pazhanisamy SK, Meng A, Wang Y, Zhou D: Reactive oxygen species and hematopoietic stem cell senescence. Int J Hematol 2011, 94:24-32.

49. Li H, Wang W, Liu X, Paulson KE, Yee AS, Zhang X: Transcriptional factor HBP1 targets P16(INK4A), upregulating its expression and consequently is involved in Ras- induced premature senescence. Oncogene 2010, 29:5083-5094.

50. Kwong J, Hong L, Liao R, Deng Q, Han J, Sun P: p38alpha and p38gamma mediate oncogenic ras-induced senescence through differential mechanisms. J Biol Chem 2009, 284:11237-11246. 
51. Bulavin DV, Phillips C, Nannenga B, Timofeev O, Donehower LA, Anderson CW, Appella E, Fornace AJ Jr: Inactivation of the Wip1 phosphatase inhibits mammary tumorigenesis through p38 MAPKmediated activation of the p16(Ink4a)-p19(Arf) pathway. Nat Genet 2004, 36:343-350.

52. Mavrogonatou E, Kletsas D: Differential response of nucleus pulposus intervertebral disc cells to high salt, sorbitol and urea. J Cell Physiol 2011, doi:10.1002/jcp.22840.

53. Farini D, Puglianiello A, Mammi C, Siracusa G, Moretti C: Dual effect of pituitary adenylate cyclase activating polypeptide on prostate tumor LNCaP cells: short- and long-term exposure affect proliferation and neuroendocrine differentiation. Endocrinology 2003, 144:1631-1643.

54. Gray MC, Hewlett EL: Cell cycle arrest induced by the bacterial adenylate cyclase toxins from Bacillus anthracis and Bordetella pertussis. Cell Microbiol 2011, 131:123-134.

55. Li Y, Yin W, Wang X, Zhu W, Huang Y, Yan G: Cholera toxin induces malignant glioma cell differentiation via the PKA/CREB pathway. Proc Natl Acad Sci USA 2007, 104:13438-13443.

56. Shen G, Xu C, Chen C, Hebbar V, Kong AN: p53-independent G1 cell cycle arrest of human colon carcinoma cells HT-29 by sulforaphane is associated with induction of P21CIP1 and inhibition of expression of cyclin D1. Cancer Chemother Pharmacol 2006, 57:317-327.

57. van Dam H, Wilhelm D, Herr I, Steffen A, Herrlich P, Angel P: ATF-2 is preferentially activated by stress-activated protein kinases to mediate cjun induction in response to genotoxic agents. EMBO J 1995, 14:1798-1811.

58. Cavigelli M, Li W, Lin A, Su B, Yoshioka K, Karin M: The tumor promoter arsenite stimulates AP-1 activity by inhibiting a JNK phosphatase. EMBO J 1996, 15:6269-6279.

59. Coso O, Teramoto H, Simonds W, Gutkind JS: Signaling from G proteincoupled receptors to c-jun kinase involves bg subunits or heterotrimeric $\mathrm{G}$ proteins acting on a ras and rac1-dependent pathway. J Biol Chem 1995, 271:3963-3966.

60. Barth H, Olenik C, Sehr P, Schmidt G, Aktories K, Meyer DK: Neosynthesis and activation of rho by Escherichia coli cytotoxic necrotizing factor (CNF1) reverse cytopathic effects of ADP-ribosylated rho. J Biol Chem 1999, 274:27407-27414

61. Bagrodia S, Derijard B, Davis R, Cerione R: Cdc42 and PAK-mediated signaling leads to jun kinase and p38 mitogen-activated protein kinase activation. J Biol Chem 1995, 270:27995-27998.

62. Minden A, Lin A, Claret F-X, Abo A, Karin M: Selective activation of the JNK signaling cascade and c-jun transcriptional activity by the small GTPases rac and cdc42Hs. Cell 1995, 81:1147-1157.

63. Dietrich C, Wallenfang $K$, Oesch F, Wieser R: Differences in the mechanisms of growth control in contact-inhibited and serum-deprived human fibroblasts. Oncogene 1997, 15:2743-2747.

64. Dietrich C, Bartsch T, Schanz F, Oesch F, Wieser R: p53-dependent cell cycle arrest induced by $\mathrm{N}$-acetyl-L-leucinyl-L-norleucinal in plateletderived growth factor stimulated human fibroblasts. Proc Natl Acad Sci USA 1996, 93:10815-10819.

65. Smith PK, Krohn RI, Hermanson GT, Mallia AK, Gartner FH, Provenzano MD, Fujimoto EK, Goeke NM, Olson BJ, Klenk DC: Measurement of protein using bicinchoninic acid. Anal Biochem 1985, 150:76-78.

66. Weiss C, Faust D, Dürk H, Kolluri SK, Pelzer A, Schneider S, Dietrich C, Oesch F, Göttlicher M: TCDD induces c-jun expression via a novel Ah (dioxin) receptor-mediated p38-MAPK-dependent pathway. Oncogene 2005, 24:4975-4983.

doi:10.1186/1478-811X-10-6

Cite this article as: Faust et al:: Differential p38-dependent signalling in response to cellular stress and mitogenic stimulation in fibroblasts. Cell Communication and Signaling 2012 10:6.

\section{Submit your next manuscript to BioMed Central and take full advantage of:}

- Convenient online submission

- Thorough peer review

- No space constraints or color figure charges

- Immediate publication on acceptance

- Inclusion in PubMed, CAS, Scopus and Google Scholar

- Research which is freely available for redistribution

Submit your manuscript at www.biomedcentral.com/submit 